\title{
HOTEL SPECIFIC DETERMINANTS OF LIQUIDITY-EVIDENCE FROM THE HOTELS IN AP VOJVODINA
}

\author{
Nada Milenković ${ }^{1}$ \\ Jelena Andrašić ${ }^{2}$ \\ Slobodan Andrašićc ${ }^{3}$
}

DOI: https://doi.org/10.31410/tmt.2019.123

\begin{abstract}
The aim of this chapter is to analyze the tourism sector in Vojvodina in terms of business liquidity of the hotels registered on the territory of the Province. The AP Vojvodina consists of 45 municipalities in which there are 220 hotels registered. The liquidity of the hotel industry depends on external and internal factors. In this research internal factors were considered in order to determine the reasons of the liquidity of the hotels in AP Vojvodina in the period of 2014-2018. The empirical studies include multivariate analysis of variances, as well as multiple regression models which enable identifying liquidity levels of hotels and how these internal factors affect the liquidity. The liquidity is measured by current liquidity ratio in the first model and quick liquidity ratio in the second model. The results of the empirical studies have shown that the impact of the indebtedness and sales growth is more intense on current liquidity than the quick liquidity ratio.
\end{abstract}

Keywords: liquidity, internal factors, hotels, AP Vojvodina.

\section{INTRODUCTION}

$\mathrm{T}$ he tourism sector is of great importance to any national economy, because "in the last thirty years, tourism and the hospitality industry within it have grown enormously and are now one of the most significant service sectors, accounting for more than $11 \%$ of world GDP and employing more than 10\% of the workforce worldwide"(Milenković, Andrašić, \& Kalaš, 2017, p. 198). Considering the complexity of this sector, it can be concluded that a large number of factors affect its development, from infrastructural factors, through the quality of the offered services, to the natural resources that a country possesses (Dimitrić, Tomas Žiković, \& Matejčić, 2018). Some of these factors depend on the human component and the degree of development of an economy, while some depend solely on the geographical location and natural resources of the country and cannot be affected. This research discusses the factors that can be influenced and which are related to micro level determinants, concretely at the hotel level.

The region covered in this research is the region of AP Vojvodina. According to the Tourism Development Strategy (Ministry of Trade Tourism and Telecommunication, 2016), the region of Vojvodina stands out as one of the tourism clusters, among Belgrade, Eastern and Western Serbia, which should be the growth carrier of the tourism sector of the Republic of Serbia. As the tourism sector covers a wide range of activities and services (Ministry of Trade Tourism and Telecommunications, 2019), the subject of analysis in this research is the hospitality industry, more precisely within the sector the hotels operating in it. Hotels are considered as a part of the hospitality industry, which provides domestic and foreign tourists with accommodation services and other services related to accommodation. Hotels imply a higher level of comfort and quality of service than other type of

\footnotetext{
University of Novi Sad, Faculty of Economics in Subotica, Segedinski put 9-11, Subotica, Serbia University of Novi Sad, Faculty of Economics in Subotica, Segedinski put 9-11, Subotica, Serbia University of Novi Sad, Faculty of Economics in Subotica, Segedinski put 9-11, Subotica, Serbia
} 
accommodations (Barjaktarović, 2013). Due to their importance and position in relation to other accommodation capacities, this research they will serve as the subjects of research and analysis.

Lately, the AP Vojvodina is offering countryside tourism, business tourism in order to attract more tourists. The number of tourists in this Province is in increase, which can be seen on the Figure 1.

The concentration of the hotels in the Province is uneven so that they are mainly located in bigger cities like Novi Sad 25.5\% (56 of 220), Subotica 14.5\% (32 of 220), Zrenjanin 5\% (11 of 220). On the other hand, there are other accommodation facilities in small cities but they are not registered as hotels, some of them are countryside houses, villas, hostels etc.

It is noteworthy, according to Vojvodina's Tourist Organization, that the number of foreign tourists' overnight stays increased by as much as $22 \%$ (243,139 nights) in the first half of 2018 compared to the same period in 2017. The increase in the number of overnight stays of domestic tourists is $11.6 \%$ (339,467 nights). Novi Sad had the largest share in the number of overnight stays in the first half of 2018 , with a $29.3 \%$ increase in the total number of overnight stays (203,437 nights), compared to 2017.

The aim of this chapter is to point out on the importance of the liquidity of the hotels in AP Vojvodina in the considered period of time from 2014 till 2018. The liquidity of the hotels is important from the perspective of long-term stable operations and raising the quality of the services in the hotel sector in Vojvodina. In order to assure the quality of the services, hotels cannot struggle with liquidity. On the other side, the expenses cannot be reduced on the behalf of the service quality. In the hospitality sector the non-financial indicators are sometimes more important than the financial once, especially when it comes to hotels survival (Gémar, Moniche, $\&$ Morales, 2016). Non-financial and financial indicators in this specific industry should be considered simultaneous in order to achieve the best performances (Elbanna, Eid, \& Kamel, 2015).

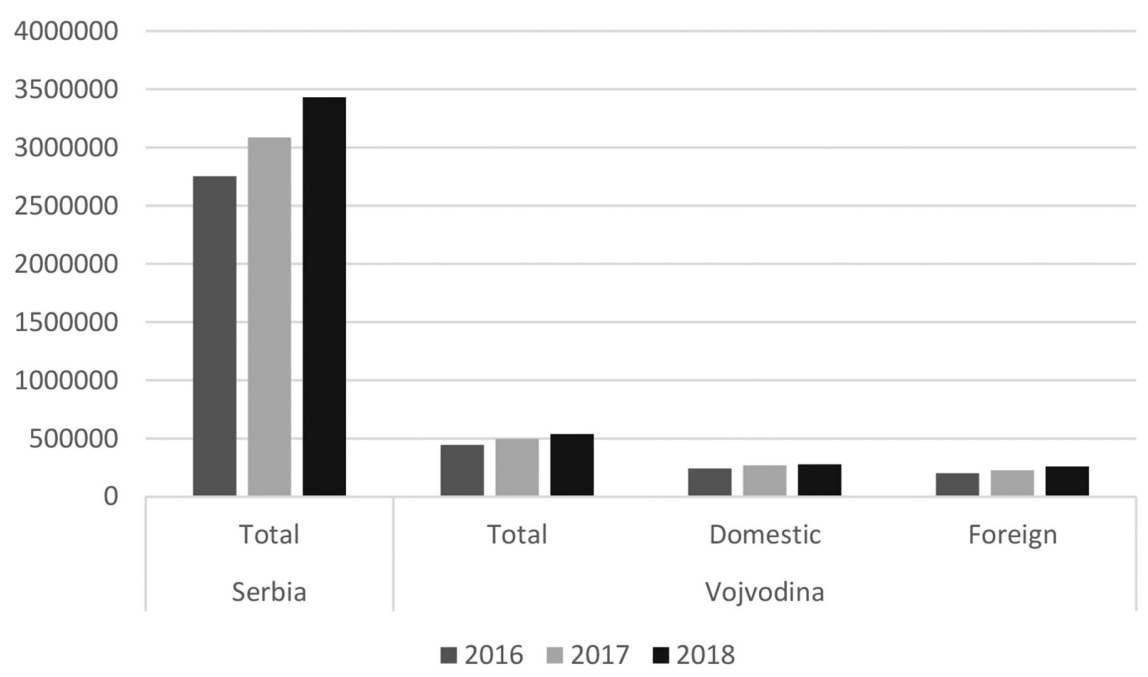

Figure 1. Number of tourists in AP Vojvodina

Source: Based on Statistical Office of the Republic of Serbia data

This research is structured as follows. The first part is representing the Introduction, this section explains the basic goals and reasons for the research. The second part deals with the Literature review, which represents the theoretical background of the research, presenting the results of the 
earlier undertaken researches regarding the liquidity, and liquidity determinants. This section forms the basis for defining regression models. The third part is about explaining the research methodology and the used data, along with explaining the indicators. The fourth part analyses by figures the hotel sector of Vojvodina in the five-year period in terms of the business indicators and liquidity ratios. The fifth part represents the results of the research, i.e. the impact of the defined determinants on the liquidity ratios in AP Vojvodina for the period 2014-2018. The last part Conclusion explains the results of the research and suggests further research.

\section{LITERATURE REVIEW}

The most important component for the operational performance of entities, as well as their value, is the working capital management (Heryán, 2018). Cash flow intensity positively impacts the technical efficiency in the hotel industry (Yuan, Li, \& Zeng, 2018). The available literature and articles are mainly based on an analysis of the hotels' profitability, cost reduction and longterm business analysis, while the liquidity analysis of the business is neglected. The contribution of this research is certainly that it addresses the topic that is not enough mentioned in the literature, although it is a daily problem faced by hotels.

The literature has dealt with liquidity issues in different ways. One approach is analyzing the length of the period during which receivables from customers are collected or the length of the loans taken from the financial institutions, and in that way this approach is dealing with the reason why some liquidity indicator is high or low. The other approach is on the contrary dealing with other determinants, which can be external or internal, that might had affected the liquidity ratios. The approach taken by the authors in treating liquidity issues by analyzing the influencing factors which might have affected the liquidity ratios.

Some of the authors who have treated the issue as described above is among others Kruse (2002), who analyzed the impact of debt ratio, profitability ratio among other variables, on the liquidity and that way also on the decision of the management to asset sales. Kim, Mauer \& Sherman (1998) investigated the impact of debt ratio, sales, size and profitability on firms liquidity, and they found a negative relationship of these determinants with firms liquidity. When it comes to the relationship between earnings, debt and liquidity Huberman (1984) came to the results that low earnings are associated with low liquidity, and external financing is negatively influencing the liquidity. The determinant used in this research match up with the determinants used by Soo Cheong, Chun-Hung \& Ming-Hsiang (2008)this study used canonical correlation analyses by examining the interrelationships between cross-balance-sheet accounts of hotel companies. The study confirmed that hotel companies followed the four common practices about the crossbalance-sheet interdependencies identified in the other industries. This study also discovered a few unique financing features of the hotel industry: (1, who were investigating the financial behaviour in the hotel industry. Authors dealing with the same issue of determinants of liquidity and the trade-off between liquidity and profitability were also Elbanna et al. (2015), Mun \& Jang (2015), Škuflić \& Mlinarić (2015).

Based on the findings of the study undertaken by Elbanna et al. (2015) the authors of this research base they regression models as well as using the analogy between the determinants that affect profitability (G. M. Agiomirgianakis, Magoutas, \& Sfakianakis, 2013; G. Agiomirgianakis \& Magoutas, 2012; Dimitrić, Tomas Žiković, \& Arbula Blecich, 2019; Dimitrić et al., 2018; Nunes, Serrasqueiro, \& Sequeira, 2009; Tan, 2017) the same way as they impact the liquidity. 


\section{DATA AND METHODOLOGY}

In order to complete the research a sample of hotels registered on the territory of AP Vojvodina was taken. There are 45 municipalities in the territory of AP Vojvodina, and under the classification of activities which refers to 551-hotels other entities there are 220 hotels registered for the five-year period from 2014-2018. This is to be considered as the population of the hotels in Vojvodina, because subjects with incomplete data were excluded from the population, the sample was reduced to 478 observations. In this research secondary data was used which was obtained from Scoring ("Scoring," 2019). Scoring is a data base that aggregates all available data from financial statements of all business entities registered in Serbia.

Table 1. Review of the explanatory variables

\begin{tabular}{|c|c|c|c|}
\hline Symbol & Variable & Description & Source \\
\hline \multicolumn{4}{|c|}{ Dependent variable } \\
\hline $\mathrm{CL}$ & Current liquidity ratio & $\begin{array}{c}\text { Current assets } \\
\text { Current liabilities }\end{array}$ & $\begin{array}{l}\text { Authors calculation based on } \\
\text { the financial statement's data }\end{array}$ \\
\hline QL & Quick liquidity ratio & $\begin{array}{c}\text { Current assets - inventory } \\
\text { Current liabilities }\end{array}$ & $\begin{array}{l}\text { Authors calculation based on } \\
\text { the financial statement's data }\end{array}$ \\
\hline \multicolumn{4}{|c|}{ Independent variable } \\
\hline ROA & Return on asset & Net income to total asset ratio & $\begin{array}{l}\text { Authors calculation based on } \\
\text { the financial statement's data }\end{array}$ \\
\hline ROE & Return on equity & Net income to total equity ratio & $\begin{array}{l}\text { Authors calculation based on } \\
\text { the financial statement's data }\end{array}$ \\
\hline SZ & Size & Natural logarithm of the total assets & $\begin{array}{l}\text { Authors calculation based on } \\
\text { the financial statement's data }\end{array}$ \\
\hline GRTH & Growth & $\begin{array}{c}\text { Salest }- \text { Sales }_{\mathrm{t}-1} \\
\text { Sales }_{\mathrm{t}-1}\end{array}$ & $\begin{array}{l}\text { Authors calculation based on } \\
\text { the financial statement's data }\end{array}$ \\
\hline DBT & Debt & (Total Debt) / (Total Assets) & $\begin{array}{l}\text { Authors calculation based on } \\
\text { the financial statement's data }\end{array}$ \\
\hline LAGCL & $\begin{array}{l}\text { Lagged Current } \\
\text { liquidity ratio }\end{array}$ & $\mathrm{CL}_{\mathrm{t}-1}$ & $\begin{array}{l}\text { Authors calculation based on } \\
\text { the financial statement's data }\end{array}$ \\
\hline LAGQL & $\begin{array}{l}\text { Lagged Quick } \\
\text { liquidity ratio }\end{array}$ & $\mathrm{QL}_{\mathrm{t}-1}$ & $\begin{array}{l}\text { Authors calculation based on } \\
\text { the financial statement's data }\end{array}$ \\
\hline EBIT & $\begin{array}{l}\text { Earnings before } \\
\text { interest and tax }\end{array}$ & Operating revenues - Operating expenses & $\begin{array}{l}\text { Authors calculation based on } \\
\text { the financial statement's data }\end{array}$ \\
\hline FS & Financial Stability & Long term assets to long term debt & $\begin{array}{l}\text { Authors calculation based on } \\
\text { the financial statement's data }\end{array}$ \\
\hline
\end{tabular}

Source: Authors' illustration

The empirical analysis of hotel performance was performed from the aspect of liquidity, whereby the effects of internal business factors on the performance of the hotel business were measured. The first part of the research is based on a descriptive analysis of key hotel performance indicators such as general liquidity ratios, accelerated liquidity ratios, leverage, including hotel size. Descriptive analysis was conducted through tables and Figures for the defined period of time. The second part of the research is focused on measuring and evaluating the character and intensity of the potential correlation between hotel performance indicators. As part of this empirical analysis, a multivariate analysis of the hotel was conducted to determine if there were significant differences in the level of key hotel performance indicators for the 2014-2018 time period. The last part of the empirical research involves the creation of multiple regression models to identify the effects of internal business factors on the liquidity ratios of the observed hotels. 


\section{BUSINESS INDICATORS AND LIQUIDITY ANALYSIS OF HOTELS IN AP VOJVODINA}

This part of the research analyses the important facts related to the liquidity of the hotels in AP Vojvodina for the period of 2014-2018. Among figures about facts considering the business activity of the hotel sector in Vojvodina, hereby will be yearly data about the liquidity ratios provided.

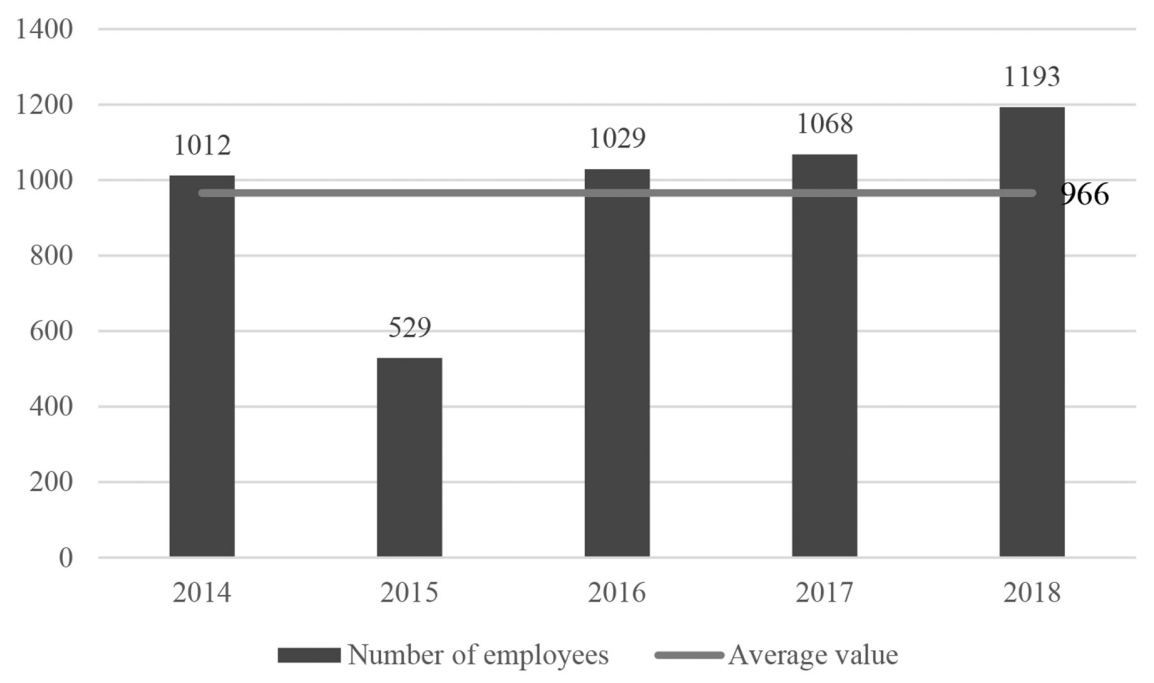

Figure 2. Number of employees in hotels in AP Vojvodina

Source: Authors' based on Scoring data

Figure 2 shows the movement of the number of employees in relation to the average value of the number of employees for the period 2014-2018. The average value is 966 employees. It can be noticed that the number of employees in hotels in the territory of AP Vojvodina increased from 2016-2018. In 2015, there was a large decrease in the number of employees compared to 2014. In 2018, 1193 workers were employed in hotels on the territory of AP Vojvodina.

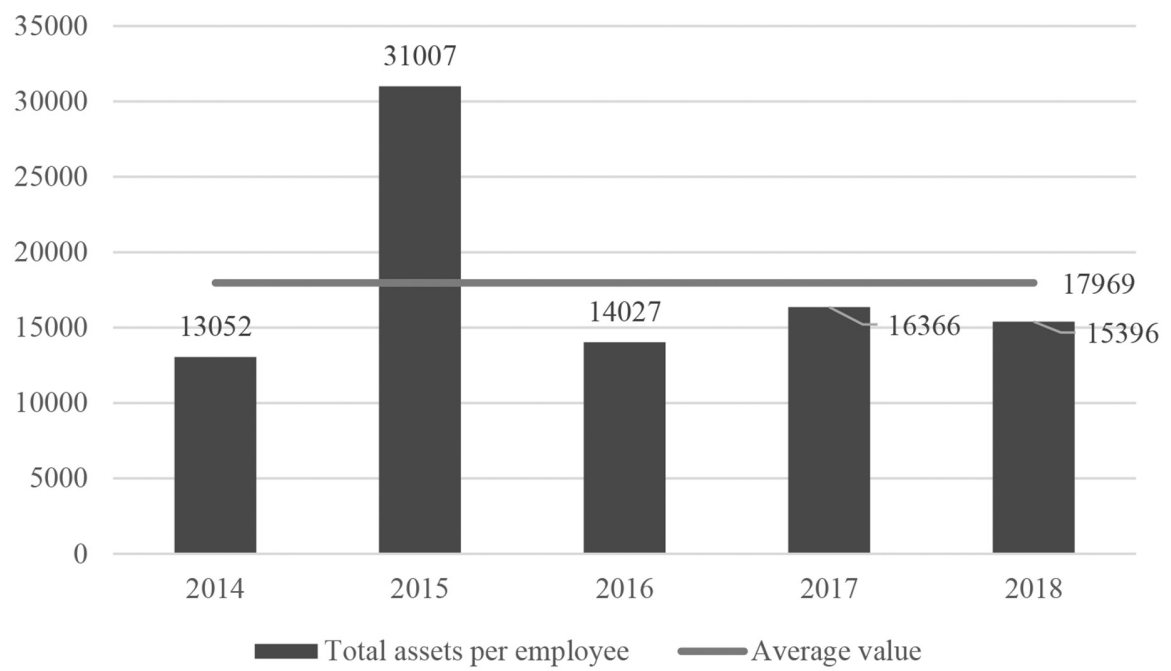

Figure 3. Total assets per employee of hotel in AP Vojvodina (in 000 RSD)

Source: Authors' based on Scoring data 
Figure 3 shows the movement of total assets per hotel employee in the territory of AP Vojvodina. The average value of total assets per employee during the analyzed period is RSD 17,969,000.00. Based on the shown data, it can be concluded that only in 2015 the value of total assets per employee was higher than the average value. In the remaining years, the value of assets per employee was lower than the average value for the period. The highest value of total assets per employee was realized in 2015 and it was amounted to RSD 31,007,000.00, while in 2014 the lowest value of assets per employee was amounted to RSD 13,052,000.00.

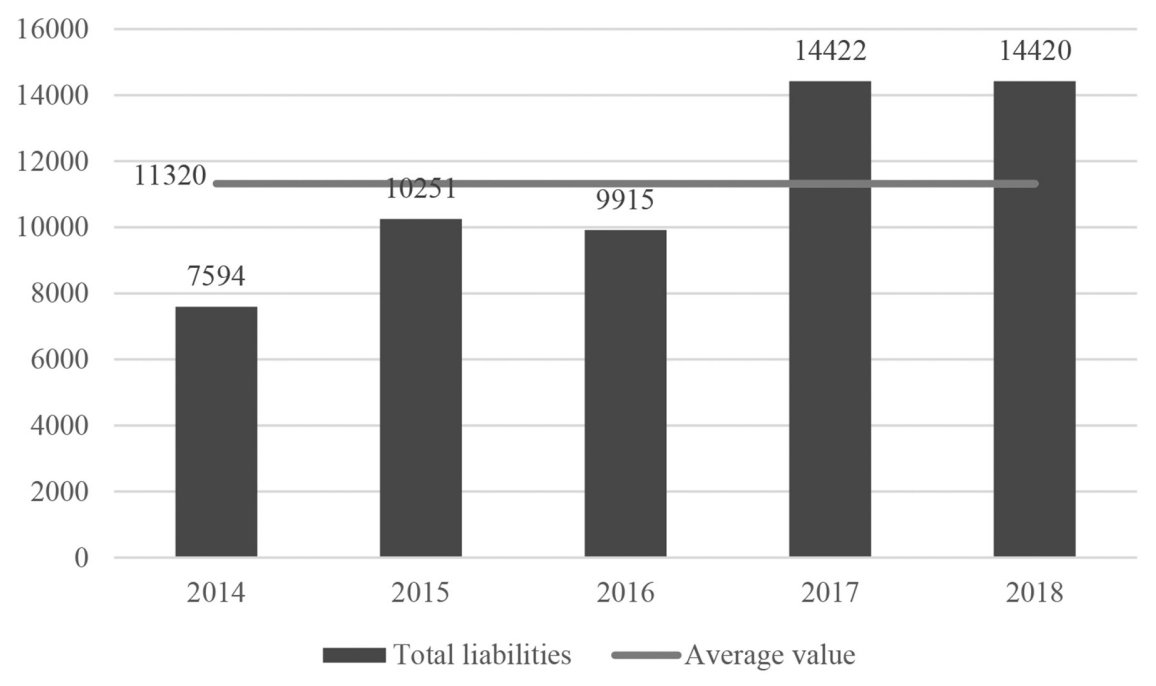

Figure 4. Total liabilities of hotels in AP Vojvodina (in 000 RSD)

Source: Authors' based on Scoring data

Figure 4 shows the trend of total hotel obligations in the territory of AP Vojvodina in the period 2014-2018. The average value of total liabilities in the analyzed period is 11,320 . It can be observed that total liabilities have trended upwards from 2016 to 2018. In the period 2014-2016. The total liabilities were lower than the average value. In 2017, there is a sharp increase in total liabilities compared to 2016. In 2017 and 2018, total liabilities were significantly higher than the average.

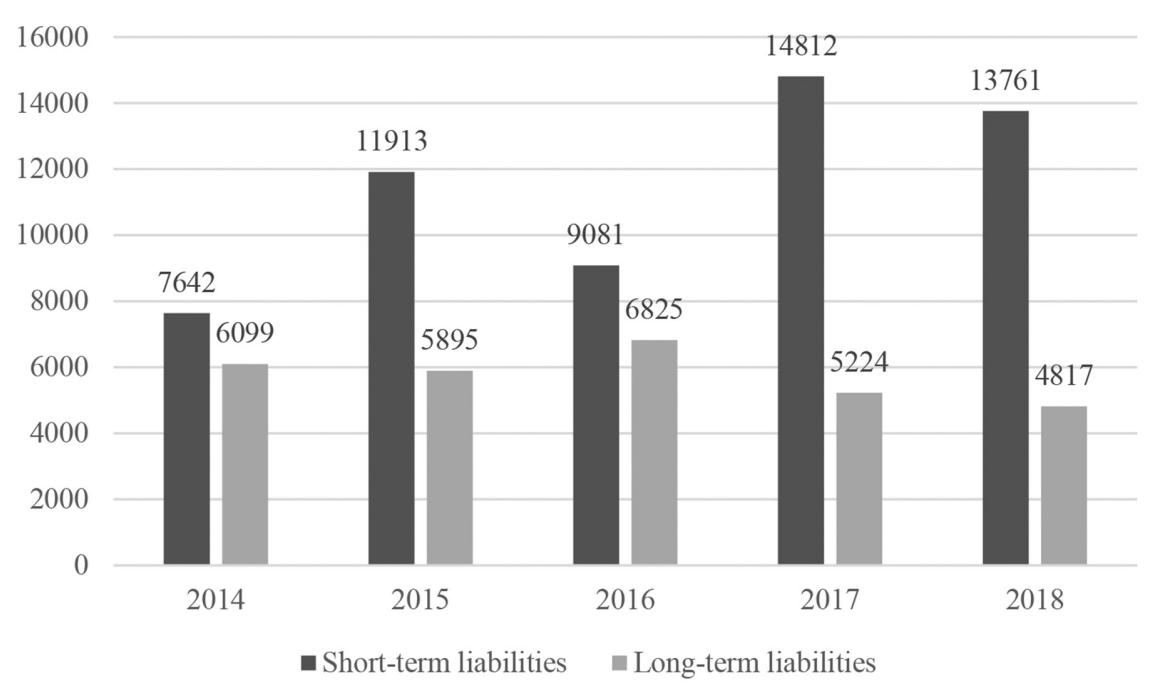

Figure 5. Short-term and long-term liabilities of hotels in AP Vojvodina (in 000 RSD)

Source: Authors' based on Scoring data 
Figure 5 shows the structure of total hotel obligations on the territory of AP Vojvodina in the period 2014-2018. It can be observed that in the analyzed period, short-term liabilities had a higher share than long-term liabilities in the total amount of the liabilities. It can also be observed that in the period 2016-2018, the structure of liabilities has moved further in favor of short-term liabilities, the reason for that was the increase in short-term liabilities and a decrease in long-term liabilities in the structure of the total liabilities. Short-term liabilities reached their highest value in 2017.

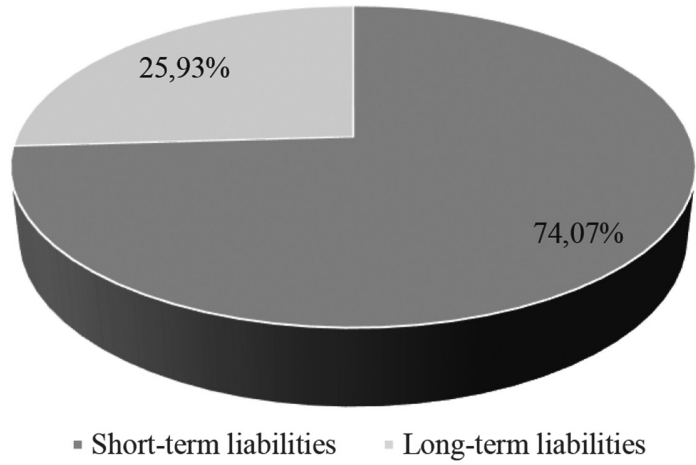

Figure 6. Structure of the total liabilities of the hotels in AP Vojvodina in 2018.

Source: Authors' based on Scoring data

According to the above shown Figure it can be observed that in 2018, the share of short-term liabilities was $74.07 \%$, of the total liabilities while the share of long-term liabilities was $25.93 \%$. Since the subjects of the research are hotels, it is common that working capital is dominant in the structure of total assets, and that they choose short termed loans as financing sources.

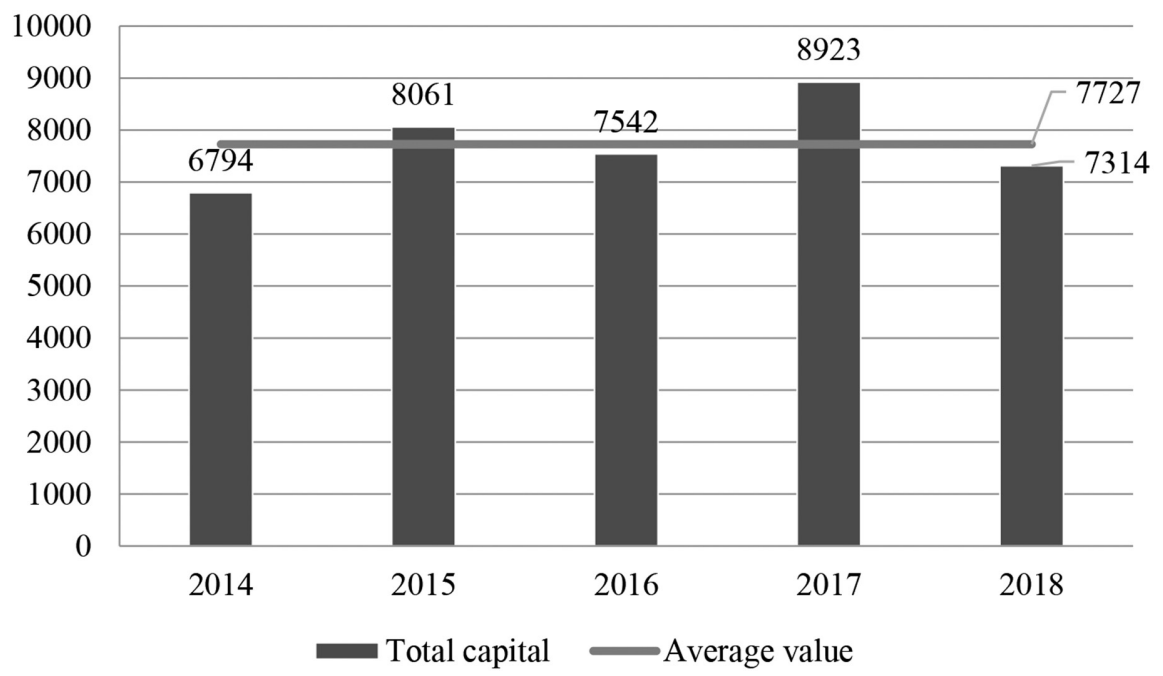

Figure 7. Total capital number of hotels in AP Vojvodina (in 000 RSD)

Source: Authors' based on Scoring data

As it can be seen on Figure the average value for the analyzed period is 7,727,000.00. It can be observed that in 2015 and 2017, higher values of total capital were achieved compared to the average value. Throughout the observed period, small fluctuations in the movement of total capital are present, and thus a slight deviation to higher or lower relative to the average value. The lowest value of total capital was present in 2014 and amounted to 6,794,000.00, while the highest value of total capital was present in 2017, and it amounted to 8,923,000.00. 


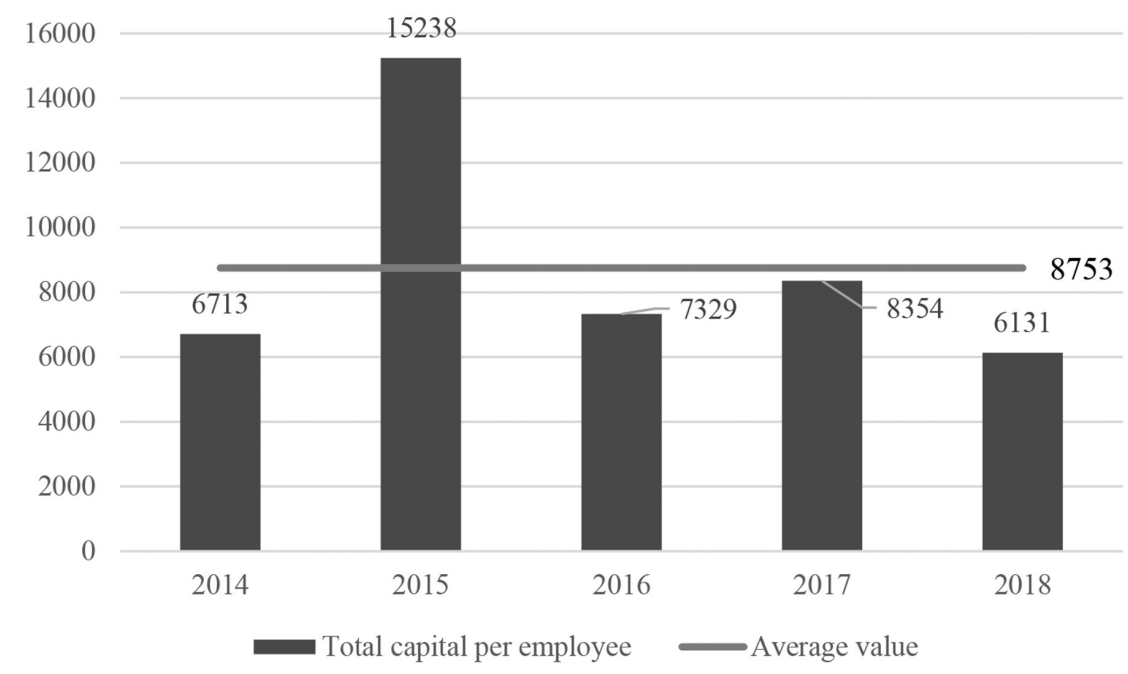

Figure 8. Total capital per hotel employee in AP Vojvodina (in 000 RSD)

Source: Authors' based on Scoring data

Figure 8 shows the movement of total capital per employee employed on the territory of AP Vojvodina in the considered five-year period. The average value of total capital per employee during the analyzed period is $8,753,000.00$ RSD. It can be concluded that only in 2015 , the total value of total capital per employee was higher than the average value. The reason for this increase was the decline in the number of employees in the hotel sector in the Province. In 2014, 2016, 2017 and 2018, a lower value of capital per employee was achieved compared to the average value.

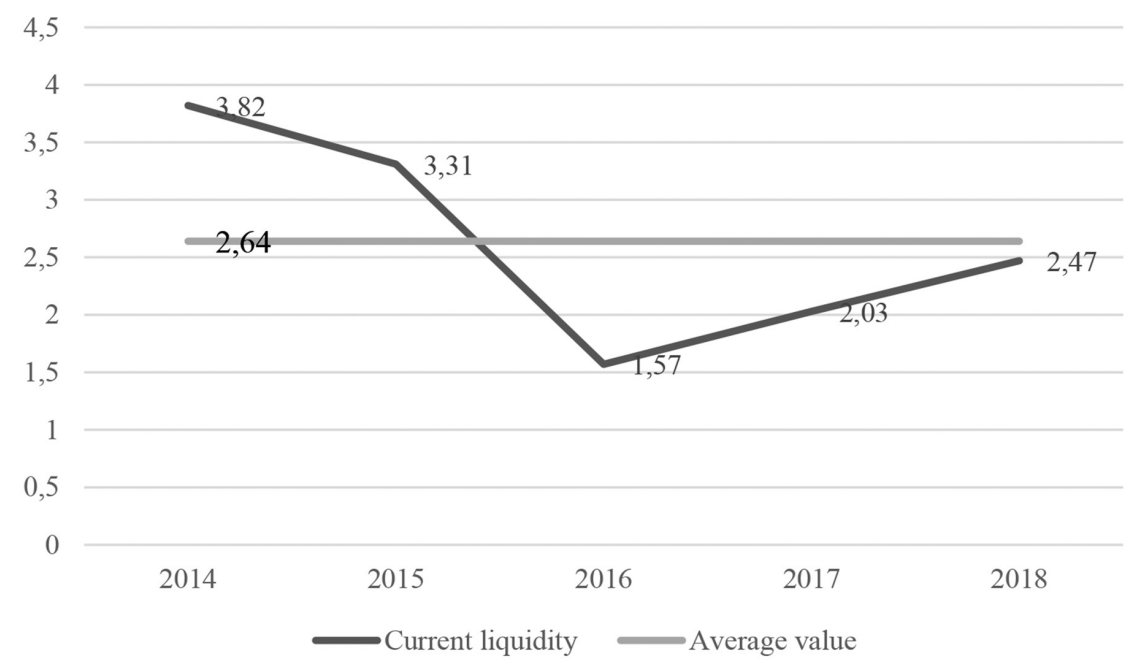

Figure 9. Current liquidity ratio of the hotels in AP Vojvodina

Source: Authors' based on Scoring data

As one of the dependent variables, current liquidity ratio is defined as the ability of an entity to settle its due liabilities using current assets. The referent value of this ratio is 2 or more than 2 (Mirović et al., 2019). This ratio does not take into account the liquidity of individual parts of current assets and is a rough measure of liquidity.

Figure 9 shows the trend of current liquidity ratios of hotels in the territory of AP Vojvodina in the period 2014-2018. The average value of this indicator is 2.64. It can be observed that the low- 
er value of the general liquidity ratio was achieved in 2016 and amounts to 1.57. In other years of the analyzed period, the movement of the general liquidity ratio was above the reference value of 2. The highest value of the general liquidity ratio was achieved in 2014 and was amounted to 3.82, which is considered to be a very high liquidity indicator. In 2014 and 2015, the movement of current liquidity ratios was above average, while from 2016-2018 the ratio of was below average. It can be concluded that in the first three years there is a declining trend in the current ratio liquidity, and in the last two years of the observed period there is an increasing trend.

The quick liquidity ratio, commonly known also as acid test, represents a much more accurate measure of liquidity because it excludes inventories as the most illiquid component of working capital. The referent value for this ratio is 1 or more than 1 (Mirović et al., 2019).

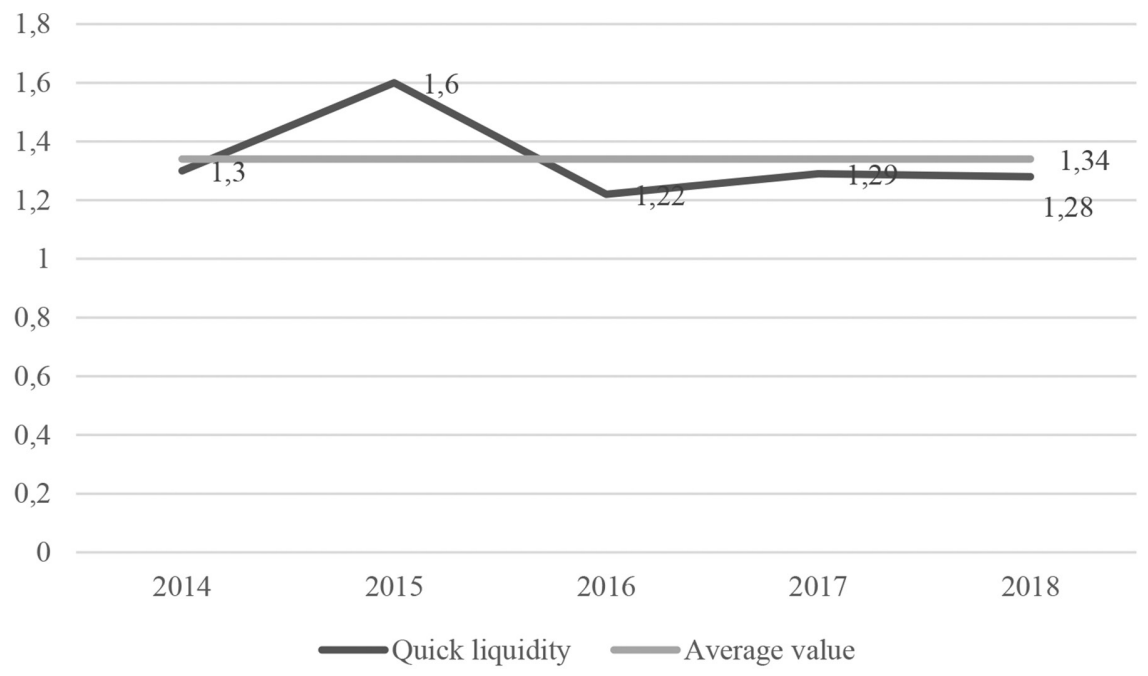

Figure 10. Quick liquidity ratio of the hotels in AP Vojvodina

Source: Authors' based on Scoring data

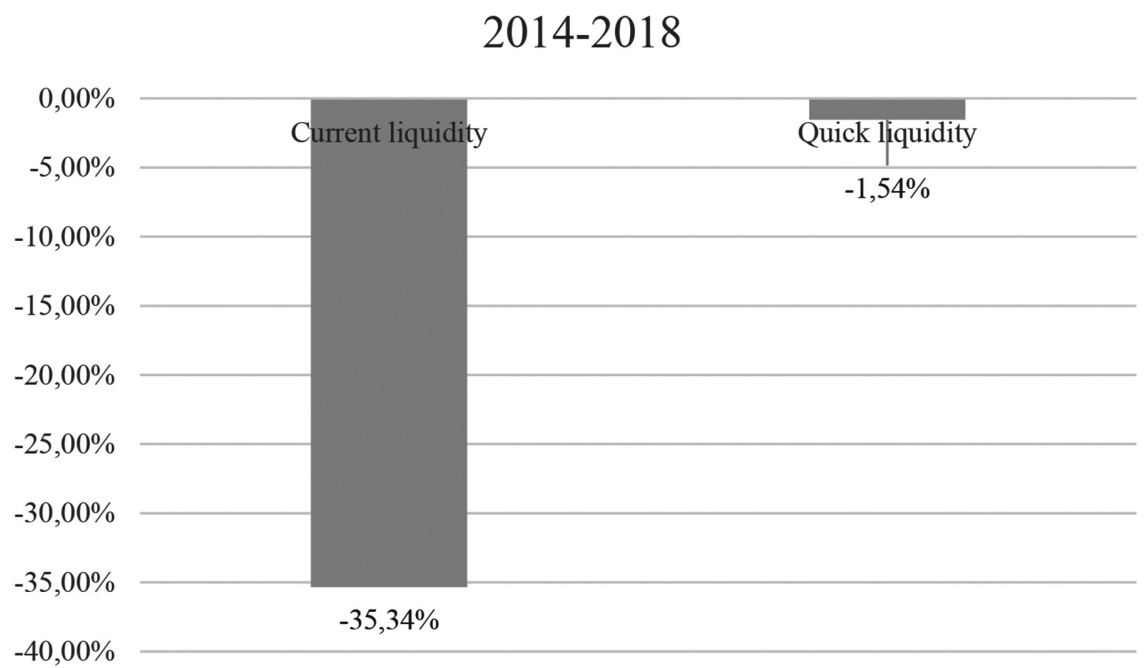

Figure 11. Comparative trend of hotel liquidity ratios in AP Vojvodina Source: Authors' based on Scoring data

Figure 10 shows the trend of quick liquidity ratio of hotels on the territory of AP Vojvodina in the period 2014-2018. The average value of this indicator is 1.34 . It can be observed that during 
the analyzed period, the value of the quick liquidity ratio was above the reference value of 1 . The highest value of the quick liquidity ratio was achieved in 2015 and was amounted to 1.6, and this value was above the average value for the period. In all other years of the observed period the value of the ratio was below the average value of this indicator.

Figure 11 shows the trend of the current and quick liquidity ratios by comparing the first and the last year of the analyzed period. Based on this overview, it can be concluded that there has been a significant decrease in current liquidity ratio in 2018 compared to 2014, while the quick liquidity ratio has slightly decreased in 2018 compared to 2014. The reason for such a significant decrease in current liquidity ratios is the increase of the short-term liabilities in the structure of the total liabilities of the hotels on the territory of AP Vojvodina.

\section{EMPIRICAL RESULTS}

After a detailed analysis of the movement of indicators by years, the collected data will be summarized by descriptive statistics. After that follows a multivariate analysis variance test in order to identify if there are significant differences in liquidity levels of hotels in AP Vojvodina for the period 2014-2018. At the end of the empirical research part two multiple regression models will be defined in order to determine the effects of the internal determinants on the analyzed hotels liquidity.

Table 2. Descriptive statistics

\begin{tabular}{|l|c|c|c|c|c|}
\hline Variable & Number of obs. & Mean value & $\begin{array}{c}\text { Standard } \\
\text { deviation }\end{array}$ & Minimum value & $\begin{array}{c}\text { Maximum } \\
\text { value }\end{array}$ \\
\hline CL & 478 & 19.51837 & 179.3555 & 0 & 2521.74 \\
\hline QL & 478 & 18.42157 & 178.6187 & 0 & 2521.73 \\
\hline ROA & 478 & -0.5596772 & 6.277963 & -128.6667 & 5.914 \\
\hline ROE & 478 & -1.421668 & 38.47663 & -793 & 105.72 \\
\hline DBT & 478 & 7.166871 & 85.01804 & 0 & 1792 \\
\hline FS & 478 & 2.18159 & 13.63284 & 0 & 217.81 \\
\hline SIZE & 478 & 1.636839 & 0.8478075 & 0 & 2.97359 \\
\hline SGR & 478 & 3.521846 & 25.11343 & -1 & 324.6721 \\
\hline EBIT & 478 & 11.77819 & 90.68455 & -528.653 & 741.4549 \\
\hline
\end{tabular}

Source: Authors' calculation

Table 3. Multicollinearity test

\begin{tabular}{|l|c|c|}
\hline Variable & VIF & $\mathbf{1 / V I F}$ \\
\hline ROA & 1.07 & 0.936408 \\
\hline DBT & 1.07 & 0.937941 \\
\hline ROE & 1.02 & 0.981984 \\
\hline EBIT & 1.02 & 0.984400 \\
\hline SIZE & 1.01 & 0.987921 \\
\hline FS & 1.01 & 0.991368 \\
\hline SGR & 1.00 & 0.998575 \\
\hline LAGGL & 1.00 & 0.998679 \\
\hline Mean VIF & $\mathbf{1 . 0 1}$ & \\
\hline
\end{tabular}

Source: Authors' calculation

The presented descriptive analysis of hotels in AP Vojvodina shows the mean value, standard deviation, minimum and maximum value of the collected research data. Based on 478 observa- 
tions, the results showed positive mean values for all indicators except profitability. Maximum value for the variable was observed by the variable current liquidity while the minimum value was spotted by the variable earnings before interest and taxes. At the same time, the variable current liquidity has the largest standard deviation compared to other variables while the variable size has had the smallest standard deviation.

In order to identify a potential multicollinearity between independent variables, the empirical study includes Variance Inflation Factor test. Results of VIF test confirmed that there is no high correlation between these variables where the average value is 1.01. It implies that variable selection is an appropriate and model satisfies condition of multicollinearity absence which is one of the fundamental assumptions in econometric analysis.

Table 4. Multivariate analysis results - liquidity level by year

\begin{tabular}{|c|c|c|c|c|c|c|}
\hline \multicolumn{2}{|c|}{ Effect } & Value & F & $\begin{array}{c}\text { Hypothesis } \\
\text { df }\end{array}$ & Error df & Sig. \\
\hline \multirow{4}{*}{ Period } & Pillai's Trace & 0.021 & 4.971 & 2.000 & 472.000 & 0.007 \\
\cline { 2 - 7 } & Wilks' Lambda & 0.979 & 4.971 & 2.000 & 472.000 & 0.007 \\
\cline { 2 - 7 } & Hotelling's Trace & 0.021 & 4.971 & 2.000 & 472.000 & 0.007 \\
\cline { 2 - 7 } & Roy's Largest Root & 0.021 & 4.971 & 2.000 & 472.000 & 0.007 \\
\hline
\end{tabular}

Source: Authors' calculation

By analyzing the level of liquidity of hotels in AP Vojvodina, it can be concluded that there are significant differences for each year of observation, because the value of Pillai's Trace test is 0.007 , which is less than the reference value of 0.05 .

Table 5. Multivariate analysis results - liquidity level by hotel

\begin{tabular}{|c|c|c|c|c|c|c|}
\hline \multicolumn{2}{c|}{ Effect } & Value & F & $\begin{array}{c}\text { Hypothesis } \\
\text { df }\end{array}$ & Error df & Sig. \\
\hline \multirow{4}{*}{ Hotel } & Pillai's Trace & 0.037 & 6.473 & 2.000 & 351.000 & 0.004 \\
\cline { 2 - 7 } & Wilks' Lambda & 0.963 & 6.473 & 2.000 & 351.000 & 0.004 \\
\cline { 2 - 7 } & Hotelling's Trace & 0.038 & 6.743 & 2.000 & 351.000 & 0.004 \\
\cline { 2 - 7 } & Roy's Largest Root & 0.038 & 6.743 & 2.000 & 351.000 & 0.004 \\
\hline
\end{tabular}

Source: Authors' calculation

Also, there are significant differences in the level of liquidity between hotels in AP Vojvodina for the observed period 2014-2018, as the value of Pillai's Trace test is 0.004 , which is less than the reference value of 0.05 .

Table 6. Test of between-subject effects for liquidity

\begin{tabular}{|c|c|c|c|c|c|}
\hline Source & Liquidity & $\begin{array}{c}\text { Type III Sum } \\
\text { of Squares }\end{array}$ & df & F & Sig. \\
\hline \multirow{2}{*}{ Period } & Current liquidity ratio & 200337.309 & 1 & 6,198 & 0.013 \\
\cline { 2 - 6 } & $\begin{array}{c}\text { Quick liquidity ratio } \\
\text { (acid test) }\end{array}$ & 180513.570 & 1 & 5.631 & 0.018 \\
\hline
\end{tabular}

Source: Authors' calculation

Based on the results from the table above, it is noticeable that the level of significance of current liquidity ratio as well as quick liquidity ratio does not exceed the reference value of 0.05 indicating that there are significant differences in the level of liquidity of the observed hotels in AP Vojvodina in the period 2014-2018. 
In order to analyse the impact of the variables mentioned in the data and methodology part, the authors created two models as follows:

\section{Current liquidity ratio model}

$$
\mathrm{CL}_{\mathrm{t}}=\beta_{0}+\beta_{1} \mathrm{DBT}_{\mathrm{t}}+\beta_{2} \mathrm{FS}_{\mathrm{t}}+\beta_{3} \mathrm{ROA}_{\mathrm{t}}+\beta_{4} \mathrm{ROE}_{\mathrm{t}}+\beta_{5} \mathrm{SIZE}_{\mathrm{t}}+\beta_{6} \mathrm{SGR}_{\mathrm{t}}+\beta_{7} \mathrm{EBIT}_{\mathrm{t}}+\beta_{8} \mathrm{LAGCL}_{\mathrm{t}}+\ldots \mathrm{e}_{\mathrm{t}}
$$

where are CL current liquidity; DBT - debt; FS - financial stability; ROA - return on assets; ROE - return on equity; SIZE - hotel size; SGR - sale growth; EBIT - earnings before interest and taxes; LAGCL - lagged current liquidity; $\beta 0$ - the constant term, $\beta$ - the coefficient of the independent variables and $\mathrm{e}$ - the error term of the equation.

Table 7. Multiple regression model - current liquidity ratio

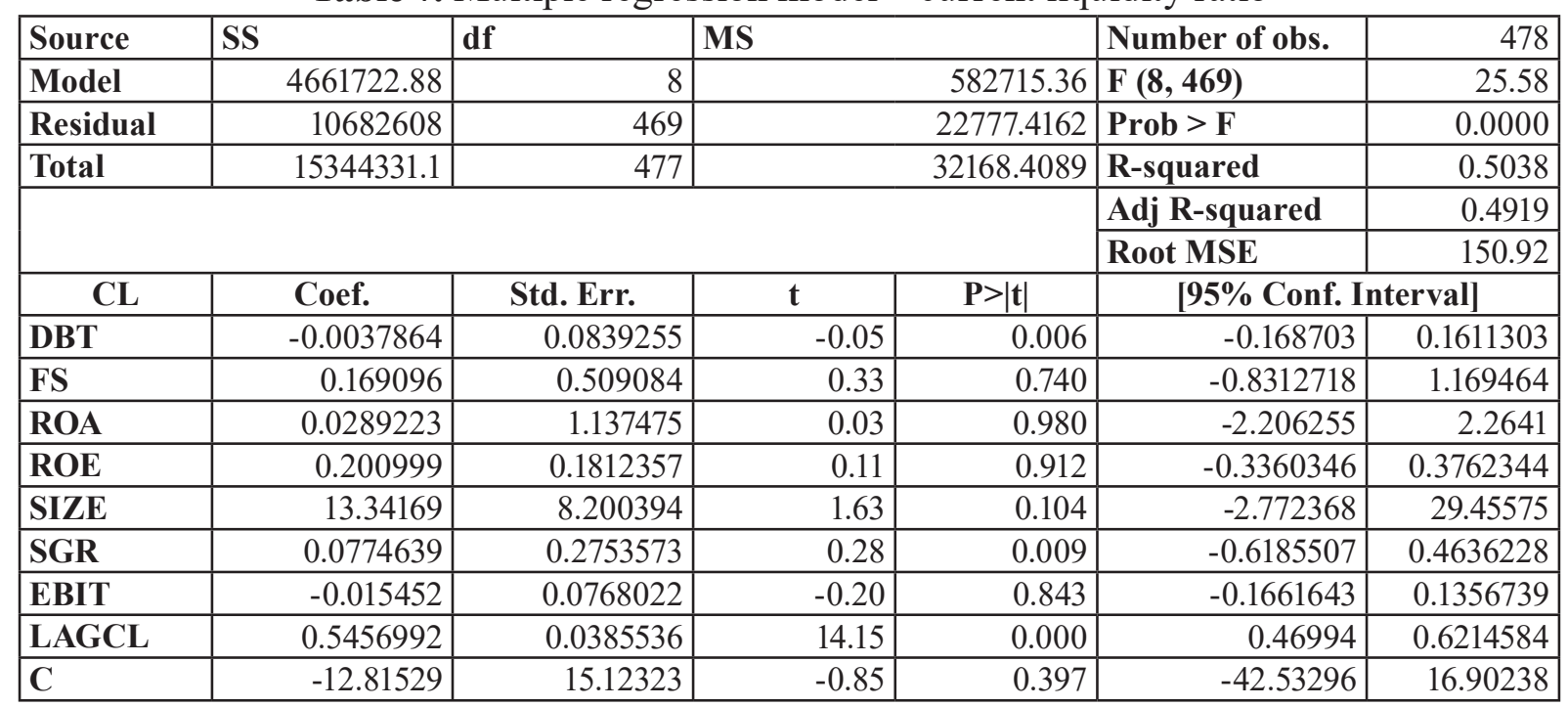

Source: Authors' calculation

The table shows the impact of indebtedness indicator, financial stability, hotel size, sales growth and operating profit on current liquidity ratio as a general measure of a hotel's short-term ability to settle its liabilities in the short term. Based on the results of the multiple regression model, the coefficient of determination is 0.5038 , which confirms that the model explained $50.38 \%$ of the variations in the independent variables. The model results show a significant impact of debt and sales revenue growth on liquidity, while other internal factors do not have a significant impact on the current liquidity ratio of the analyzed hotels. Specifically, indebtedness adversely affects hotel liquidity, with a $1 \%$ increase implying a decrease in current liquidity by $0.0037 \%$. On the other hand, the growth of sales revenue has a positive effect on the liquidity of the hotel, where a $1 \%$ increase contributes to $0.0775 \%$ liquidity growth.

After measuring and evaluating the impact of internal factors on current liquidity, a regression model aimed to measure the same on the quick liquidity ratio of the hotels is presented as follows:

\section{Quick liquidity ratio (acid test) model}

$$
\mathrm{QL}_{\mathrm{t}}=\beta_{0}+\beta_{1} \mathrm{DBT}_{\mathrm{t}}+\beta_{2} \mathrm{FS}_{\mathrm{t}}+\beta_{3} \mathrm{ROA}_{\mathrm{t}}+\beta_{4} \mathrm{ROE}_{\mathrm{t}}+\beta_{5} \mathrm{SIZE}_{\mathrm{t}}+\beta_{6} \mathrm{SGR}_{\mathrm{t}}+\beta_{7} \mathrm{EBIT}_{\mathrm{t}}+\beta_{8} \mathrm{LAGQL}_{\mathrm{t}}+\ldots \mathrm{e}_{\mathrm{t}}
$$


where are QL - quick liquidity ratio; DBT - debt; FS - financial stability; ROA - return on assets; ROE - return on equity; SIZE - hotel size; SGR - sale growth; EBIT - earnings before interest and taxes; LAGQL - lagged quick liquidity ratio; $\beta 0$ - the constant term, $\beta$ - the coefficient of the independent variables and e - the error term of the equation.

Table 8. Multiple regression model - quick liquidity ratio

\begin{tabular}{|c|c|c|c|c|c|c|}
\hline Source & SS & df & \multicolumn{2}{|c|}{ MS } & Number of obs. & 478 \\
\hline Model & 4709882.48 & 8 & \multicolumn{2}{|r|}{588735.31} & $F(8,469)$ & 26.28 \\
\hline Residual & 10508634 & 469 & \multicolumn{2}{|r|}{22406.4698} & Prob $>$ F & 0.0000 \\
\hline Total & 15218516.8 & 477 & \multicolumn{2}{|r|}{31904.6475} & R-squared & 0.3095 \\
\hline & & & & & Adj R-squared & 0.2977 \\
\hline & & & & & Root MSE & 149.69 \\
\hline QL & Coef. & Std. Err. & $\mathbf{t}$ & $\mathbf{P}>|\mathbf{t}|$ & \multicolumn{2}{|c|}{ [95\% Conf. Interval] } \\
\hline DBT & -0.0030069 & 0.0832393 & -0.04 & 0.001 & -0.166575 & 0.1605612 \\
\hline FS & 0.205158 & 0.5048586 & 0.41 & 0.685 & -0.7869068 & 1.197223 \\
\hline ROA & 0.0253741 & 1.128168 & 0.02 & 0.982 & -2.191515 & 2.242263 \\
\hline ROE & 0.0210054 & 0.1797536 & 0.12 & 0.907 & -0.3322168 & 0.3742276 \\
\hline SIZE & 14.2758 & 8.133209 & 1.76 & 0.080 & -1.706241 & 30.25784 \\
\hline SGR & 0.0715786 & 0.273107 & -0.26 & 0.003 & -0.6082434 & 0.4660862 \\
\hline EBIT & -0.0147383 & 0.0761742 & -0.19 & 0.847 & -0.1644234 & 0.1349467 \\
\hline LAGQL & 0.5503114 & 0.03839 & 14.33 & 0.000 & 0.4748738 & 0.625749 \\
\hline $\mathrm{C}$ & -15.03921 & 14.99909 & -1.01 & 0.317 & -44.51295 & 14.43453 \\
\hline
\end{tabular}

Source: Authors' calculation

The table shows the results of the multiple regression model using quick liquidity ratio as the dependent variable. The use of accelerated liquidity ratio is a more rigorous approach to measuring liquidity because it looks at the most liquid assets. This ratio excludes from the numerator of the ratio inventories as the least liquid item of current assets. The model results confirm the significant impact of debt and sales growth indicators, whereby debt is having a negative impact on the quick liquidity ratio, while sales growth is having a positive impact on accelerated hotel liquidity. This implies that a $1 \%$ increase in indebtedness contributes to a decrease in accelerated liquidity by $0.003 \%$, while, on the other hand, an increase in sales revenue enhances accelerated liquidity by $0.0716 \%$. As it can be observed, the impact of indebtedness and sales growth is more intense on current liquidity than on the quick liquidity indicator. This means that a change in these two indicators (debt and sales growth) results in a more pronounced change in the current liquidity ratio of the observed hotels.

\section{CONCLUSION}

The aim of this research was to examine the effect of the hotel specific determinants on the liquidity of the hotel sector in AP Vojvodina from 2014 to 2018. Empirical analysis has included multivariate analysis of variance as well as multiple regression models which has estimated the impact of debt, financial stability, hotel size, sale growth, earnings before interest and taxes, and lagged liquidity on the liquidity ratios defined as current liquidity and quick liquidity ratios.

Results of MANOVA test have shown a significant difference in liquidity levels between hotels in AP Vojvodina and also for the period 2014-2018. Results of the defined regression models have shown that indebtedness and sale growth have significant impact on liquidity ratios measured by current liquidity ratio and quick liquidity ratio. Although the impact of indebtedness and sales growth is more intense on current liquidity than on the quick liquidity indicator. 
The results of the regression models suggest that management should take counter-measures to increase sales revenue rather than focusing on cost reductions to provide liquidity. Cost reductions can lead to a decline in service quality, which can put the hotel business in the long run.

Another influential factor that has a significant impact on liquidity is debt. Although it has a negative impact on liquidity, in the observed period the level of indebtedness of the hotel did not endanger the liquidity. Managers have to examine the real costs and risk of financing long-term assets with short-term liabilities, because about $74 \%$ of the loans are short-termed. The shortterm liabilities might appear as a good financing solution because of the low interest rates, but the frequent use of short-termed loans, i.e. the mismatching practice, could lead to higher cost, long term instability and at the end it could increase of financial risk and jeopardize the hotels business. Recommendation for further research would be to extend the research on the analyses of the factors influencing the hotels indebtedness and to include external factors to the analyses.

\section{ACKNOWLEDGMENT}

The results of this research are part of the project named "Analysis of hotel business in AP Vojvodina from 2014 to 2018". This project was supported by Futurizam d.o.o. - tourism consulting company and Tourist Organization of Vojvodina [grant number 1324-19].

\section{REFERENCES}

Agiomirgianakis, G. M., Magoutas, A., \& Sfakianakis, G. (2013). Determinants of profitability in the Greek tourism sector revisited: The impact of the economic crisis. Journal of Tourism and Hospitality Management, 1(1), 12-17.

Agiomirgianakis, G., \& Magoutas, A. (2012). Determinants of profitability and the decision-making process of firms in the tourism sector: the case of Greece. International Journal of Decision Sciences, Risk and Management, 4(3-4), 294-299.

Barjaktarović, D. (2013). Upravljanje kvalitetom u hotelijerstvu. Beograd: Univerzitet Singidunum.

Dimitrić, M., Tomas Žiković, I., \& Arbula Blecich, A. (2019). Profitability determinants of hotel companies in selected Mediterranean countries. Economic Research-Ekonomska Istraživanja, 32(1), 1977-1993. https://doi.org/10.1080/1331677X.2019.1642785

Dimitrić, M., Tomas Žiković, I., \& Matejčić, V. (2018). Profitability determinants in the hotel industry; case of Primorje-Gorski Kotar County and Croatia. Financije-Teorija i Suvremena Pitanja. Ekonomsku Fakultet u Osijeku, 329-350.

Elbanna, S., Eid, R., \& Kamel, H. (2015). Measuring hotel performance using the balanced scorecard: A theoretical construct development and its empirical validation. International Journal of Hospitality Management, 51, 105-114. https://doi.org/10.1016/J.IJHM.2015.09.004

Gémar, G., Moniche, L., \& Morales, A. J. (2016). Survival analysis of the Spanish hotel industry. Tourism Management, 54, 428-438. https://doi.org/10.1016/J.TOURMAN.2015.12.012

Heryán, T. (2018). What Drives Liquidity of Tourism Companies? Microeconomic Evidence from Bulgaria, Czech Republic and Poland. Acta Universitatis Agriculturae et Silviculturae Mendelianae Brunensis, 66(6), 1477-1484. https://doi.org/10.11118/actaun201866061477

Huberman, G. (1984). External Financing and Liquidity. The Journal of Finance, 39(3), 895908. https://doi.org/10.1111/j.1540-6261.1984.tb03684.x

Kim, C.-S., Mauer, D. C., \& Sherman, A. E. (1998). The Determinants of Corporate Liquidity: Theory and Evidence. The Journal of Financial and Quantitative Analysis, 33(3), 335. https://doi.org/10.2307/2331099 
Kruse, T. A. (2002). Asset Liquidity and the Determinants of Asset Sales by Poorly Performing Firms. Financial Management, 31(4), 107. https://doi.org/10.2307/3666176

Milenković, N., Andrašić, J., \& Kalaš, B. (2017). Finansijska analiza sektora turizma-primer ugostiteljskih preduzeća severa Vojvodine. In MODERN MANAGEMENT TOOLS AND ECONOMY OF TOURISM SECTOR IN PRESENT ERA (pp. 197-212). Association of Economists and Managers of the Balkans-UDEKOM.

Mirović, V., Mijić, K., Andrašić, J., Kalaš, B., (2019). Performanse poslovanja preduzeća - finansijski i računovodstveni aspekt. Ekonomski fakultet u Subotici, Subotica.

Ministry of Trade Tourism and Telecommunication. (2016). Tourism Development Strategy of the Republic of Serbia for the period from 2016 to 2025. Government of Republic of Serbia.

Ministry of Trade Tourism and Telecommunications. Law on Tourism, Pub. L. No. "Sl. glasnik RS," br. 17/2019 (2019). Serbia: "Sl. glasnik RS”, br. 17/2019.

Mun, S. G., \& Jang, S. (Shawn). (2015). Working capital, cash holding, and profitability of restaurant firms. International Journal of Hospitality Management, 48, 1-11. https://doi. org/10.1016/J.IJHM.2015.04.003

Nunes, P. J. M., Serrasqueiro, Z. M., \& Sequeira, T. N. (2009). Profitability in Portuguese service industries: a panel data approach. The Service Industries Journal, 29(5), 693-707. https://doi.org/10.1080/02642060902720188

Scoring. (2019). Retrieved October 10, 2019, from https://www.scoring.rs/

Škuflić, L., \& Mlinarić, D. (2015). Mikroekonomske determinante profitabilnosti Hrvatske hotelske industrije. Ekonomski Pregled, 66(5), 477-494.

SooCheong, J., Chun-Hung, T., \& Ming-Hsiang, C. (2008). Financing behaviors of hotel companies. International Journal of Hospitality Management, 27(3), 478-487. https://doi. org/10.1016/J.IJHM.2007.08.010

Tan, Y. (2017). Hotel-specific, industry-specific and macroeconomic determinants of profitability in London Hotel industry: Structure-Conduct-Performance or Efficient-Structure.

Yuan, B., Li, J., \& Zeng, G. (2018). Corporate liquidity management and technical efficiency: Evidence from global listed hospitality enterprises. International Journal of Hospitality Management, 74, 40-44. https://doi.org/10.1016/J.IJHM.2018.02.023 